\title{
Multi-stakeholder dialogue on formal and informal forms of public transport in Harare, Zimbabwe: Convergence or divergence perspective
}

\author{
Authors: \\ Tatenda $\mathrm{Mbara}^{1}$ \\ Smart Dumba² \\ Tapiwa Mukwashi ${ }^{2}$ \\ Affiliations: \\ ${ }^{1}$ Department of Transport \\ and Supply Chain \\ Management, University of \\ Johannesburg, South Africa \\ ${ }^{2}$ Department of Rural and \\ Urban Planning, University of \\ Zimbabwe, Zimbabwe \\ Correspondence to: \\ Tatenda Mbara \\ Email: \\ tmbara@uj.ac.za \\ Postal address: \\ B17 Laborie Village, 1 \\ Menton Road, Auckland Park \\ 2092, Johannesburg, \\ South Africa \\ Dates: \\ Received: 08 Apr. 2014 \\ Accepted: 22 July 2014 \\ Published: 21 Nov. 2014 \\ How to cite this article: \\ Mbara, T., Dumba, S. \& \\ Mukwashi, T., 2014, 'Multi- \\ stakeholder dialogue on \\ formal and informal forms of \\ public transport in Harare, \\ Zimbabwe: Convergence \\ or divergence perspective', \\ Journal of Transport and \\ Supply Chain Management \\ 8(1), Art. \#140, 9 pages. \\ http://dx/doi.org/10.4102/ \\ jtscm.v8i1.140

\section{Copyright:} \\ (C) 2014. The Authors \\ Licensee: AOSIS \\ OpenJournals. This work \\ is licensed under the \\ Creative Commons \\ Attribution License.
}

Cities in the developing world are growing both geographically and demographically. This growth has increased pressure on services, including the public transport systems used by the majority of people. In the last two decades public transport provision has undergone considerable changes. Concomitant to these changes there has been debate on the form of public transport to be operated. Such debate has been informal, general, and at times academic, and therefore not able to provide substantive understanding of the views of key stakeholders. Zimbabwe has had an explosion of informal transport activity in the form of minibuses, and decision makers appear to be in a policy dilemma because of a need to strike a balance between maximising passenger welfare whilst protecting the livelihoods of indigenous minibus operators and striving to build an efficient and environmentally sound urban transport system. Critical questions for policy dialogue in this conundrum include, inter alia: How do stakeholders perceive the current public transport system? How can public transport be sustainably provided? This study seeks to answer these questions using a case study of Harare. A qualitative research approach blended with some quantitative aspects was used. Initial steps involved the identification and clustering of key urban public passenger transport stakeholders, followed by structured and unstructured interviews. Although there is lack of consensus on the form of public transport that the City of Harare should adopt, there is a strong view that a mass transit system is the backbone of sustainable public transport.

\section{Introduction}

Cities in sub-Saharan Africa share a common history in development of their public transport systems. The cities' geographical and demographic growth have increased pressure on services, including the public transport systems which are used by the majority of the people. In the last two decades public transport provision has undergone considerable changes in institutional setup as well as the type of vehicles operated.

Although there has been an increase in private motorisation, a large section of the population in the cities of developing countries cannot afford to have their own personal motorised means of transport (Joewono \& Kubota 2005). This population relies on walking, cycling, and formal and informal public transport for meeting its mobility needs. In Zimbabwe, akin to many developing countries, the experience has been that Government agencies are unable to provide adequate formal public transport. An 'informal public transport' system has emerged to cater for the mobility needs unmet/partially met by formal public transport systems (Golub 2003). Informal transport relies more heavily than the formal sector on traditional knowledge and resources, family labour and ownership, small-scale operations and labour-intensive techniques, and offers low barriers to entry for potential participants (Rakowski 1994).

For varying reasons there is a struggle on the part of policy makers, politicians and other urban actors to control informality in the transport sector.

In the discourse of public transportation academics contend that conventional formal transport systems, if managed well, provide more comfort, greater safety and a more environmentally acceptable travel option than minibuses. Kumar and Barrett (2008) state that large buses hold the promise of relieving the growing congestion of African cities; however, Cervero (1991) observed that these vehicles cannot always serve residential areas with narrow entryways, poor roads or difficult terrain.

The 'formal versus informal debate' regarding the form of public transport system in the cities of developing countries is ongoing. This article explores stakeholder views on the form that public transport should take in Harare, the capital city of Zimbabwe. It also seeks to ascertain the extent 
of convergence and/or divergence on the acceptability or otherwise of formal versus informal means of transport. The article will provide lessons to interested parties, as hitherto the debates have been highly technical and devoid of an understanding of the views of key stakeholders.

The answers to the following questions, constituting the public transport problem, will be unpacked through interviews with key stakeholders, making a major departure from other studies, which tend to place heavy reliance on professionals: What is the best institutional set-up for future public transport provision for Harare?; What is the favoured mode of transport?; What are the operational challenges associated with a coordinated system between formal and informal transport?; and How can public transport be sustainably provided?

\section{Literature review}

Gwilliam (2008:3) identified a post-colonial 'regulatory cycle' in urban public transport operations, which started through 'many of the countries which were formerly British or French colonies until the late 1940s inheriting urban bus sectors'. These bus sectors were privately operated. For example, in Dar es Salaam, Tanzania, a British company known as Dar es Salaam Motor Transport (DMT) started to operate conventional public bus services in 1949 (Kanyama \& Carlsson-Kanyama 2005). In Nairobi public transport started in 1934 when the Overseas Motor Transport Company of London was given a franchise on 12 routes. In Kampala, Uganda, the privately owned Uganda Transport Company (UTC) held the exclusive franchise for bus services until its nationalisation in 1972 (Kumar \& Barrett 2008). Prior to nationalisation UTC's only competitors were small shared taxis. The modus operandi in all three of these cities prior to independence was based on a franchise that permitted the service provider to operate with minimal competition from other operators, with fares regularly reviewed and services scheduled (Kumar \& Barrett 2008; Gwilliam 2005; Maunder \& Mbara 1996).

The DMT offered a good-quality service in Dar es Salaam from 1949 and was nationalised in 1970 'in line with the then socialist ideology that the economy ought to be in the control of the state' (Kanyama \& Carlsson-Kanyama 2005). The new company was jointly owned by Government and the City of Dar es Salaam. Fares were subject to Government control and, due to the socialist thinking of the then Government, consideration was not given to company viability, but was rather based on perceptions of what the people could afford. Consequently service efficiency was affected and the company failed to cope with an increasing city population. In Kampala the privately owned UTC held the exclusive franchise for bus services until its nationalisation in 1972 (Kumar \& Barrett 2008). The policies enacted by governments ultimately led to a decline in conventional public transport and concomitantly gave birth to the informal sector.
The dichotomy between the formal and informal sectors can be viewed along several key dimensions. Table 1 contrasts the two sectors in terms of service structure, scheduling, reliability, labour market segmentation, class, and internal organisation. The prevalence of small-scale, labour-intensive and adaptive services does not fully characterise the informal realm, however. Informal services also imbue subtle yet important social relationships (Portes, Castells \& Benton 1989). Vital to their existence are the often highly personalised relationships between service providers and clients, as well as unwritten social norms and codes of behaviour amongst competitors themselves.

On attaining democratisation (independence), some governments took decisions which directly affected the provision of public transport. Some nationalised the urban public passenger transport sector, whilst others reinforced regulatory controls. Controls were principally applied to the politically sensitive area of fares that companies could charge. The control of fares negatively affected revenues that were needed to maintain and replace buses (let alone acquire more vehicles for expansion) (Gwilliam 2008). Figure 1 summarises the consequences of charging low fares. Consequently, some companies went bankrupt and in some cases personnel pulled out, leaving governments to appoint new and inexperienced people to operate buses, ultimately resulting in the dearth of conventional urban public transport systems.

The period after the 1970s was marked by a decline in conventional bus services and a dramatic increase in informal modes, resulting in some cases in a complete disappearance of the former. The competition posed by the informal sector compounded the problems of conventional operations. In Kenya the matatus (informal sector), which started operating in the 1950s 'as a solution to mobility segregation of the colonial era' (Sclar, Touber \& Alexander 2007:10) were legalised in 1973. In Tanzania the privately operated minibuses (the daladala) were legalised in 1983. However, the

TABLE 1: Dichotomy between formal and informal means of transport.

\begin{tabular}{|c|c|c|}
\hline Dimension & Formal transport system & $\begin{array}{l}\text { Informal transport } \\
\text { system }\end{array}$ \\
\hline Service structure & Fixed route, standardised & Variable route, adaptive \\
\hline Scheduling & Fixed timetable & Market-driven, adaptive \\
\hline Reliability & Reasonably dependable & Inconsistent \\
\hline Economic standing & Middle and upper class & Lower class, poor \\
\hline Legitimacy & Legal, regulated & Illegal, unregulated \\
\hline Assets and capitalisation & Intensive & Minimal \\
\hline Political influence & Strong, empowered & Weak \\
\hline Society and culture & Modern & Traditional \\
\hline Financing and credit access & Commercial banks & Family and loan sharks \\
\hline Skill levels & Knowledge based & $\begin{array}{l}\text { Cognitive labour-based, } \\
\text { adaptive }\end{array}$ \\
\hline Technology & High-tech & Low-tech \\
\hline Internal organisation & $\begin{array}{l}\text { Orderly, vertically } \\
\text { integrated }\end{array}$ & $\begin{array}{l}\text { Less structured, horizontally } \\
\text { integrated }\end{array}$ \\
\hline Legal status & Registered & Registered, unregistered \\
\hline
\end{tabular}
Source: Portes, A., Castells, M. \& Benton, L. (eds.), 1989, The informal economy:
advanced and developing countries, Johns Hopkins University Press, Baltimore 


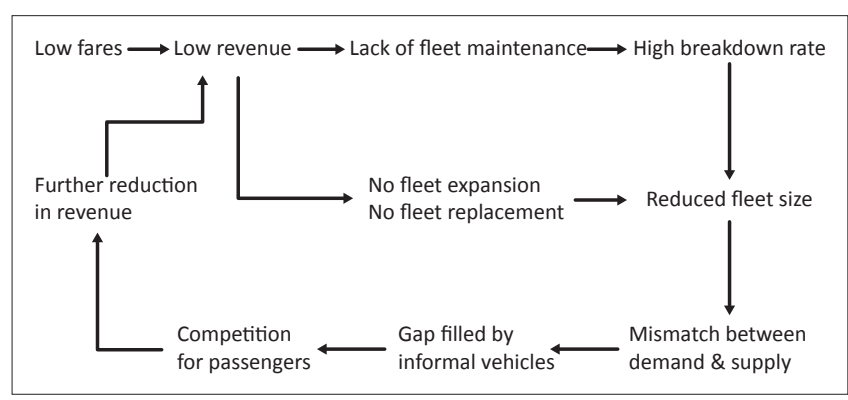

Source: Authors' own creation

FIGURE 1: Consequences of lower fares.

growth in population and unprecedented congestion which is a common phenomenon in these cities has ignited fresh thinking on the informal sector's contribution to meeting the demand for public transport.

Consequent to the pressure on policy makers to review public transportation services, informal transit services have been subjected to one or another form of official response. Cervero (2000) categorises the available regulatory options as acceptance, recognition, prohibition and regulation:

- Acceptance: Either an official act allowing the activity to remain, without reaction or regulation, or inability or lack of interest in enforcing any of the other options.

- Recognition: Legitimising the system and taking away a bit of the uncertainty that remains with mere acceptance.

- Prohibition: This is enforced through threat of fines, vehicle confiscations and even arrests in response to the continued operation of illegal services. This is rarely done, mainly due to a lack of enforcement, manpower and political will.

- Regulation: This option is more complex and costly. Generally the city department already responsible for public transit regulation will add a new agency in charge of overseeing regulation of the paratransit services (Cervero 2000). The justification for regulation is based on the fact that urban public passenger transportation is for the 'public good', which directly affects large groups of people, their safety, productivity and happiness, and uses public infrastructure and resources (Kahn 1970).

Increasingly, small-capacity vehicles are now being seen as an inefficient user of road space which could not sustain the demand for urban public transport in the long term. Authorities in many sub-Saharan cities are endorsing largercapacity public transport systems as the appropriate solution to address the public transport challenges. Nigeria was the first country to introduce the bus rapid transit system (BRT) in 2008. In South Africa BRTs have been introduced in Johannesburg and Cape Town and construction in Pretoria is in progress. Other cities are also considering the BRT option.

The regulatory cycle has thus travelled a full circle, which began with privately operated, scheduled conventional buses. This was followed by takeover of these conventional operations by either governments or municipalities. The third stage saw emergence of the informal sector, which is still dominant. The fourth phase entails a movement towards larger-capacity vehicles, a situation that existed prior to the 1970s. Similar to what occurred in other countries, Harare is on the third stage of the cycle (as discussed in the section below) and decision makers appear to be in a dilemma in terms of the next course of action to take. This motivated us to carry out this study.

\section{Overview of public transport provision in Harare}

According to Maunder and Mbara (1996), a British company, United Transport Overseas Services (UTOS), started to operate services in Harare using conventional buses as a sole provider with a guaranteed profit as far back as 1954. The bus-operating company had an agreement with the City of Harare to service a $26 \mathrm{~km}$ radius franchise area from the main post office. At the end of the financial year the company was paid the balance in the event that a $20 \%$ return on capital employed was not achieved. Thus public transport was operated under a monopoly and subsidised when necessary. Arguments then advanced for such an operational regime 'to provide a cheap continuous and reliable service for all sections of the community' (Jordan 1983:133).

In 1980 Zimbabwe gained its independence, and the postdemocratisation Government 'pursued a policy targeted at redressing the socio-economic imbalances, which had existed prior to 1980' (Maunder \& Mbara 1996:9). The Government took three critical decisions which directly impacted on public transport. Firstly, the responsibility of fares determination was moved from the City of Harare to Central Government, and fares were no longer regularly revised and adjusted. Secondly, subsidies were cancelled as they were seen as a disincentive to manage the company, with a proviso that economic fares would be granted - which in practice turned out not to be the case. In addition, subsidies were perceived as a transfer payment, where the same ratepayers are taxed to subsidise their own public transport. Thirdly, Peugeot station wagon vehicles with a seating capacity of seven passengers (although 10 was the norm) were legally licensed to provide a shared taxi service on set routes (Maunder \& Mbara 1996).

The above measures marked a watershed in the decline of conventional public transport in Harare. Revenues for the conventional bus operator started to drop due to uneconomic fares and competition from informal operators. Consequently the company found itself without adequate revenue to maintain the existing fleet or replace the ageing fleet, let alone buy buses for expansion (Maunder \& Mbara 1996). In response to the deteriorating situation, the Zimbabwean Government acquired 51\% shares in the conventional bus company, followed by outright ownership a few years later when UTOS pulled out.

However, Government participation failed to arrest the situation, as the service could not keep abreast with demand. The increasing public transport demand-supply gap encouraged the proliferation of pirate taxis (informal 
sector), which started to surface on high-density corridors. The growth of the informal sector was given impetus by the Economic Structural Adjustment Programme (ESAP) which was introduced in 1990. The thrust of the ESAP was geared towards the liberalisation of the economy. In essence, this meant removal of price and economic controls, allowing the market to direct the performance of the economy (Government of Zimbabwe 1992). This led to the deregulation of urban passenger transport in 1993, when for the first time privately operated public transport vehicles were legally permitted to operate in urban areas. Privately operated vehicles in the form of minibuses (popularly referred to as 'kombis') have mushroomed and now dominate the entire public transport market in Harare, resulting in a dearth of conventional bus operators.

\section{Research method and design Setting}

Harare is the capital and principal industrial and commercial city of Zimbabwe. Harare has in the last few years been affected by the country's debilitating macro-economic situation. Greater Harare (including two contiguous settlements) has a current population of 2.1 million people, representing $16.2 \%$ of the total population in the country (Zimbabwe National Statistics Agency 2012). The rising population has in turn resulted in the physical expansion of the city as well as an increase in density. Despite the adverse economic environment, the people have found a reasonably cheap source of motor vehicles from Japan and Asia. Motor cars arrive in the country daily in great quantities, and the majority of them are destined for Harare. The situation is compounded by a large number of minibuses, which are the sole means of public transport. This has created severe congestion in the city, affecting people's access to socioeconomic services. The major question is how the urban public transport system in Harare can be sustainably improved. This article seeks to answer this question by ascertaining key stakeholders' views on the form that public transport in Harare should take.

\section{Research design}

In this study the authors employed a qualitative research approach blended with some quantitative aspects. Initial steps in this study involved identification of key stakeholders in urban public passenger transport (Table 2) in Harare. This form of stakeholder mapping was achieved through the creation of four major clusters of stakeholders: policy formulators and implementers (public sector); policy research cluster (academia); policy consumers 1 (transport operators); and policy consumers 2 (users).

Within the policy formulators and implementers cluster key stakeholders were the Government (central and local) and agencies - the Zimbabwe National Roads Administration and Zimbabwe Traffic Safety Council. The policy research cluster, constituted purposefully, selected University of Zimbabwe departments (Economics, Engineering, Geography and Rural and Urban Planning, Institute of Environmental Studies) and the Scientific and Industrial Research Development Centre. In policy consumers' cluster 1 (transport operators) the research team identified the Greater Harare Commuter Operators Association, the Zimbabwe United Passenger Company (ZUPCO), Long distance Bus Operators Association, and Harare Residents Association. The final cluster, policy consumers 2, comprised commuters who use public transport on a daily basis.

\section{Data collection and analysis}

After the stakeholder-mapping process an opinion survey questionnaire was designed. At the heart of the questionnaire was the need for an in-depth understanding of stakeholders'

TABLE 2: Stakeholders engaged.

\begin{tabular}{|c|c|c|c|c|}
\hline Clusters & Relevant government ministries & $\begin{array}{l}\text { Relevant departments and } \\
\text { parastatals }\end{array}$ & Operators & Users \\
\hline \multirow{5}{*}{$\begin{array}{l}\text { Policy formulators and } \\
\text { implementers cluster }\end{array}$} & Ministry of Transport & Department of Physical & - & - \\
\hline & Ministry of Local Government & Planning & - & - \\
\hline & - & City of Harare & - & - \\
\hline & - & Traffic Safety Council & - & - \\
\hline & - & $\begin{array}{l}\text { Zimbabwe National Roads } \\
\text { Administration }\end{array}$ & - & - \\
\hline \multirow[t]{5}{*}{$\begin{array}{l}\text { Policy researchers cluster } \\
\text { (academia) }\end{array}$} & - & $\begin{array}{l}\text { Department of Rural and Urban } \\
\text { Planning }\end{array}$ & - & - \\
\hline & - & Department of Economics & - & - \\
\hline & - & Department of Civil Engineering & - & - \\
\hline & - & Department of Geography & - & - \\
\hline & - & Institute of Environmental Studies & - & - \\
\hline \multirow[t]{3}{*}{ Policy consumers cluster } & - & - & Informal (minibus) operators & - \\
\hline & - & - & Informal pirate taxi operators & - \\
\hline & - & - & Conventional bus operators & - \\
\hline Public transport users cluster & - & - & - & 300 users on 10 corridors \\
\hline
\end{tabular}


perceptions with regard to both formal and informal forms of public transport. In respect of policy formulation and research clusters, the questionnaire was directed to the most relevant senior persons, whose responsibilities involved transportation matters. Face-to-face interviews were conducted which provided an opportunity to probe the interviewees further for clarity. For policy consumers 1 interviews were held with the Associations' Executive.

As for the commuters, the authors first had to deal with sample size issues. We first established the major local public transport route corridors originating in Harare City Centre, radiating out and terminating in the various residential suburbs. In this endeavour 10 route corridors were identified, from which commuters' perceptions were elicited. Three hundred commuters (30 per corridor) were interviewed during the afternoon peak period. A combination of random and purposeful sampling was implemented to ensure gender balance.

The questionnaires used for all of the clusters were very similar, with very few variations to suit each cluster. The questions revolved around the prevailing status of urban transport, legislative framework, modal preference and reasons for this, challenges and recommendations for future improvement.

Data were analysed per cluster in order to identify common views emerging from each cluster. The main areas of interest on which views were sought were public transport problems experienced, remedial measures and future preferred public transport mode.

\section{Results}

As alluded to in the methodology section, information for this article was collected using qualitative and quantitative methods. The former methodology was confined to the major stakeholders - Government (public sector), academia and the private sector operators - whilst the latter methodology was administered to users. The findings of the study detailed below are divided into related sections.

\section{Public sector}

The dialogue conducted with the public sector (Government and associated departments) brought out the following as the main public transport problems experienced in Harare:

- congestion, which hampers the smooth flow of traffic

- use of small vehicles (minibuses) for public transport

- uncomfortable vehicles which are unsafe and crowded

- irrational behaviour of minibus drivers

- high-speeding vehicles, with a high rate of accidents

- illegal operations, as approximately $60 \%$ of public transport vehicles are not registered

- institutional challenges amongst the different Government organs that administer public transport.
In respect of remedial measures to address urban public transport challenges, the dominant solution cited by all organs of Government revolved around the need to introduce mass transit systems, which meant bigger buses. It is instructive to mention that at the time of conducting interviews for this article, Government through the Ministry of Transport launched the first National Transport Policy for the country. In respect of urban transport, the policy statement and strategies (Government of Zimbabwe 2012) state as follows:

To improve the supply of public transport services without compromising passenger safety and comfort and transport adequacy in urban areas and the strategies to achieve this were stated as inter alia:

- Promoting the use of high capacity transport modes such as standard train/articulated buses which are economic and efficiently use road space and gradually phasing out combis and minibuses with a capacity less than 26 seats;

- Introducing controlled deregulation on high-demand routes and franchising or tendering system on low demand routes. (pp. 15-16)

However, one Ministry official expressed caution and the need to be sensitive to the political angle, as small vehicles are sustaining and supporting the livelihoods of the poor. Getting rid of these small vehicles was deemed 'politically suicidal' (verbal expression by a Director in the Ministry of Transport).

Whilst the proposal for a mass transit system is plausible, the crucial question is how exactly will this be achieved? A number of suggestions were proposed. The first entails the present minibus operators forming an association which can negotiate with Government to facilitate investment in bigger buses that would be solely used in urban areas.

The second proposal involves the franchising of high-demand corridors and awarding contracts to conventional bus operators. Small vehicles would be banned from operating on these routes. This suggestion was once mooted but was opposed by politicians on the grounds that employment would be negatively affected.

Public-private partnership (PPP) was the third suggestion recommended. In essence this would require the local authority to enter into joint ventures with the private sector to operate conventional buses.

The National Transport Policy also articulates a fiscal strategy that would dissuade the importation of smaller public passenger vehicles by charging prohibitive duties. Concomitantly, those importing large-capacity vehicles would be incentivised to do so. In the long term, the smaller vehicles will gradually reduce.

\section{Academia}

Engagements with the four relevant departments (Rural and Urban Planning, Engineering, Economics and the Institute of Environmental and Studies) at the University of Zimbabwe revealed the following urban public transport challenges: 
- high congestion costs which are detrimental to the economy

- uneconomic use of space resulting from use of small vehicles

- compromised road safety, emanating from an aged fleet and the operational characteristics of minibuses, which is costly to the economy

- negative environmental externalities brought about by the kombis (air, water and noise pollution)

- lack of skills capacity to address the issues, resulting in policy pronouncements devoid of empirical justification.

Academia and the public sector share the view that introduction of high-occupancy vehicles, due to their higher load factors, will go a long way towards resolving urban public transport challenges in Harare. The argument advanced was that bigger vehicles reduce the number of vehicles on roads, lessening the burden on infrastructure demand - and pollution per passenger kilometre will also be significantly reduced.

This cluster emphasised the need to conduct in-depth studies before any decision can be taken on adopting formal or informal forms of public transport. One academic argued that the solution is not simply substituting one mode with another, as the present transport infrastructure leaves a lot to be desired. A recommendation was put forward to conduct a rigorous analysis of the economics of operating conventional buses and minibuses in the local environment. The structure of our urban routes may be such that the two modes can complement each other.

Academia identified congestion as a serious issue that stalls productivity and economic growth in the City of Harare, and lamented the non-availability of research information that quantifies the costs of congestion to the economy.

\section{Transport operators}

Transport operators that were interviewed were minibus operators, through their umbrella association, ZUPCO, the last company to operate conventional bus services in urban areas (but now solely operating long-distance services), longdistance bus operators and conventional bus operators who operate only during the peak periods. The following were the challenges of urban transport cited by this group:

- inadequate infrastructure, including terminal facilities

- unfavourable tariffs in urban areas

- high operational costs in urban areas

- highly peaked demand

- operating with second-hand vehicles

- financial support from banks not forthcoming

- operationally, regulations and laws not working in favour of the informal sector

- unfavourable institutional arrangements of dealing with two Ministries, the Ministry of Transport and Ministry of Local Government.

Minibus operators are of the view that they are providing a convenient and demand- responsive service to the urban populace with their small vehicles. As minibuses are currently the dominant provider of public transport in Harare, it would be unrealistic to phase them out overnight. Equally, it would be difficult for anyone to introduce a big bus and start competing with small buses which fill up quickly. They argued that any changes to capacity have to be wholesale.

All transport operators (urban and long distance) agree that operating costs in urban areas are high and tariffs are not favourable compared to those charged on long- distance routes. High operating costs are caused by high congestion levels, which affect the turnaround time for buses, resulting in reduced revenue as a result of fewer trips. In addition, the congested environment increases the frequency of engaging gears through recurrent stop-starts, resulting in increased operational costs.

Notwithstanding the fact that urban public transport is deregulated, current long- distance bus operators are reluctant to deploy their buses in urban areas. Apart from high operational costs, they perceive competition with minibuses as not being undertaken on an even playing field. The modus operandi of minibuses is such that vehicles can stop anywhere en route, and they also take a shorter time to fill during off-peak periods. This argument was corroborated by a few conventional bus operators who operate what one operator described as a 'hit and run' urban peak period service. The operators admitted that it was not possible for conventional buses to compete with minibuses which fill up quickly during the off-peak period. Equally, the shorter turnaround time of minibuses and their ability to stop anywhere en route would make conventional buses unattractive during the peak period. Thus the consensus from operators was that conventional buses and minibuses could not compete on the same routes.

\section{Public transport users}

In the process of conducting research for this article it was evident that operators and policy makers are always arguing about their perceived solutions to the urban public transport problem, without taking into consideration users' views. To this end it was necessary to conduct a survey to ascertain the views of public transport consumers. A total of 300 questionnaires (30 per corridor) were administered to public transport users from 10 major transport corridors radiating from Harare City Centre.

In response to the question of users' liking minibuses and pirate taxis (whether they see them as good or not), a marginal 159 (53\%) were of the view that they were a good mode of transport, citing some of their operational advantages such as speed, efficiency and convenience. The other $141(47 \%)$, who disregarded kombis as a good mode of urban public transport, were frustrated by (amongst others) the pricing system (peak pricing) and poor customer care. Analysis of the 300 questionnaires revealed the advantages and disadvantages of using minibuses, as summarised in Table 3. 
TABLE 3: Advantages and disadvantages of kombis and pirate taxis in Harare.

\begin{tabular}{ll}
\hline Advantages & Disadvantages \\
\hline Negotiable pricing system (off-peak) & Higher prices (peak hour) \\
$\begin{array}{l}\text { Convenient with flexible pick-up } \\
\text { and drop-off points }\end{array}$ & Poor customer care \\
$\begin{array}{l}\text { Reduced travel times due to } \\
\text { higher speed }\end{array}$ & $\begin{array}{l}\text { Gender-insensitive } \\
\text { Over-crowded and filthy conditions }\end{array}$ \\
\hline
\end{tabular}

Source: Research findings, 2013

By and large, small public passenger vehicles met passengers' expectations in terms of travelling speed (less travel time) and convenience (because of the hail and ride system). The public generally cited the 'pick up and drop anywhere' operations of kombis as their greatest advantage.

When the conventional bus factor was brought into the picture, mixed views from the users emerged. Regarding users' recommendations of the most appropriate mode of transport for Harare, 169 (53\%) cited conventional buses, whilst $64(21 \%)$ were in favour of minibuses and pirate taxis. The remaining $67(22 \%)$ recommended both modes of transport.

One interesting finding from the survey was that in as much as the public cited minibuses and pirate taxis as a good urban public transport mode, they were also of the view that conventional buses must be reintroduced. On further probing and triangulation of questions it emerged that the public indeed need minibuses and pirate taxis. Recommendations for reintroduction of conventional buses mainly stemmed from the lack of customer care and business ethics characterising the informal transport sector. Through textual analyses and cross-tabulations from SPSS, it emerged that responses for reintroduction of conventional buses mainly came from female passengers, who are in most cases victims of visual and verbal abuse from kombi crew and touts. For example, one agitated woman from the City Centre - Glen Lorne corridor had this to say:

'It is regrettable to note that somebody without even 36 units at Grade 7 is given the responsibility to drive passengers, even doctoral persons like me. Conventional buses should have been introduced like yesterday.'

The woman is basically referring to seemingly low levels of education of most kombi crew, due to their lack of customer care practices and gender insensitivity. Surprisingly, one of the rank marshalls shouted back at the woman in local language, translated here as 'Your PhDs should yield fruitful results for you rather than shelving them'. This snapshot represents many uncaptured cases of women using the kombis as their form of public transport to and from work who experience abuse.

\section{Historical memory and conventional buses}

After the age/public transport recommendation analysis it emerged that respondents who were above 40 years of age mainly supported the idea of reintroducing conventional buses. This support largely emerged from their historical memory of the relatively reliable and affordable services of ZUPCO during the 1980s and early 1990s. However, the majority, who were less than 40 years of age, generally were not in favour of reintroducing ZUPCO as a form of urban public transport. The term 'ZUPCO' on its own reminded them of a poorly run parastatal with a host of problems, from longer passenger waiting times to unreliable operations and longer travel times. Hence, some were quick to say ZUPCO is 'a non-starter' and that kombis were better. From their memory they knew the ZUPCO of the 1990s, which greatly declined due to the effects of transport deregulation instituted in 1993.

\section{Informal public transport and employment}

Another dimension that came to light during this survey was the issue of employment for those in the informal public transport sector if this system were to be phased out. For example, the kombi crews were at first unwilling to assist in answering the questionnaires as they feared that introduction of buses would lead to loss of their jobs. It was interesting to note that the commuters themselves also sympathised with the kombi crew in terms of their possibility of being unemployed if kombis were to be banned or phased out.

\section{Ethical considerations}

For the qualitative study, permission to conduct interviews was sought from the organisation. This entailed visiting the organisation and explaining the objectives of the study prior to the actual interview. All the organisations approached were forthcoming as they perceived the issue being studied to be a critical one.

With regard to public transport users, permission to carry out the survey was initially granted by the Municipality. The actual participation of individuals was voluntary. This was explained to public transport users selected for interview. Interestingly no users turned down the request for an interview. The only challenge was to manage the crowd which would congregate around the person being interviewed, at times chipping in with their own responses.

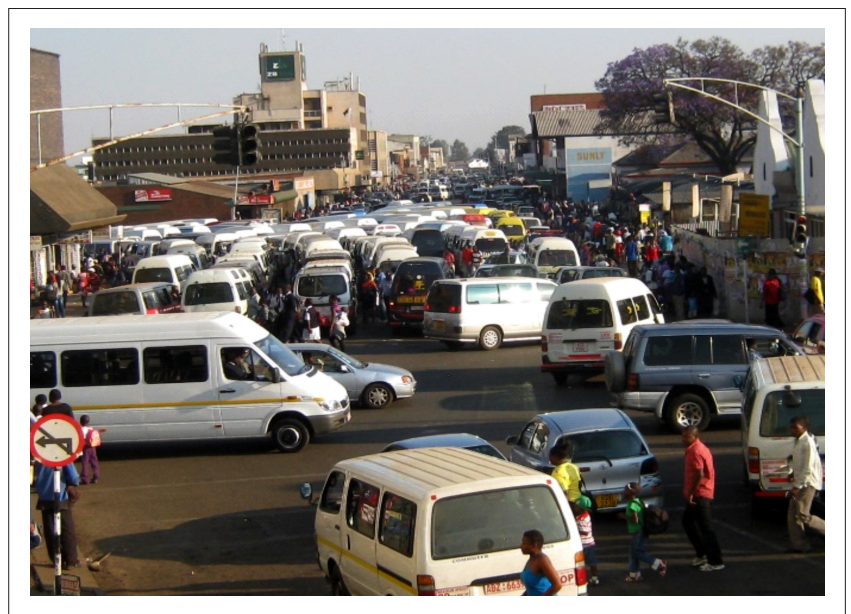

Source: Photo provided by authors

FIGURE 2: Street totally blocked by minibuses. 
In both the qualitative and quantitative surveys assurance was given to respondents that no names would be published and results would be reported collectively. The assurance ensured greater cooperation by respondents.

\section{Discussion}

Congestion and conduct of minibus drivers are two concerns that were cited by almost all of the clusters. These two concerns are clearly evident in photographs (Figures 2 and 3) taken during the course of the survey in Harare. In Figure 2 an entire street has been taken over by minibuses, making it impossible for others to use the road. In Figure 3 a minibus is seen loading in the middle of a street, making it difficult for other vehicles and pedestrians to cross. These were observed to be common scenes in the city.

Decision makers from the public sector were unequivocal on the need to introduce conventional buses as the main mode of transport in Harare. The legislative framework is already, in place, but what is required is a commitment to implement the policy. The three possible options - minibus operators forming an association to acquire conventional buses, franchising high-demand corridor routes, and a PPP - all require a massive capital injection, which is difficult to secure in the current economic environment. The policy makers' sympathy with the informal sector's employment support for the poor may either stall or be used as an excuse for failure to introduce mass transit systems. However, it can also be argued that a properly organised public transport system which is efficient and affordable supports the social needs of the users, who invariably are the poor.

Decision makers have failed to 'walk the talk' on their support of a larger-capacity public transport system. On 19 December 2013 the Zimbabwean Government presented its 2014 budget, which apart from mentioning the desirability of establishing a fund to rehabilitate roads, was silent on improvement of public transport in urban areas.

Academia acknowledges the high transport costs that emanate from congestion and recognises the importance

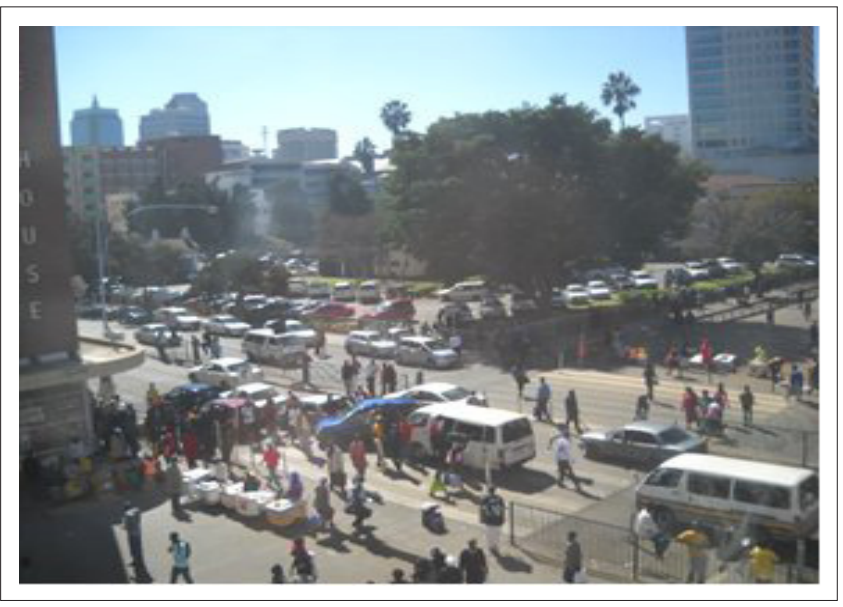

Source: Photo provided by authors

FIGURE 3: Minibus loading in the middle of a road. of conventional buses as a solution to public transport challenges in Harare, with the proviso that implementation of a mass transit system needs to be supported by viability studies. As Harare has conspicuous transport corridors, the role of smaller vehicles on shorter routes that feed long-haul routes should be explored. In addition, academia lamented the paucity of technical skills required to address urban transport challenges in Harare, and such a lack is indeed evident. At the time of conducting the survey the transport department in the City of Harare had no employees with relevant qualifications in transport. Therefore any intended changes to improve the public transport system will be hampered by a lack of technical capacity.

Minibus operators see themselves as performing a commendable service using small-capacity vehicles. A major issue that was raised by operators pertains to the high costs of operating big buses in urban areas. Apart from the generic disadvantages related to high operating costs resulting from congestion, an analysis of tariffs revealed that the revenue in terms of cents per passenger kilometre (CPPK) is higher for long-distance operations compared to urban operations. The current CPPK for long-distance routes is approximately 3 whilst it is 2.5 for urban areas. The unfavourable urban CPPK has dissuaded conventional bus operators from deploying vehicles in urban areas. Therefore, in the event that conventional buses are introduced in the City of Harare, their viability can be threatened by the lower CPPK. As one operator remarked, '... it is impossible to operate conventional bus services in Harare without a subsidy'. Such a statement may not be far from the truth, as most conventional bus operators are subsidised. The minibus operators would prefer the status quo to continue, but if forced to operate big buses they want to be given first preference.

Public transport users expressed mixed feelings. There is a strong preference for small public passenger vehicles, principally for the convenience and speedy service they offer. However, when it comes to the recommendation of a future mode of transport, a significant number of users cited the conventional bus.

The public transport user study yielded important dimensions: the gender and public transport dimension, and historical memory and conventional buses dimension. Female users, who in the main are not in favour of minibuses, strongly rebuked the untoward behaviour of minibus crew. On engaging the crew on this wayward behaviour, pressure to achieve revenue targets was given as the explanation.

ZUPCO ceased to operate conventional services in Harare in 1998. Interestingly, users were able to recall their experiences with ZUPCO, some acknowledging a relatively efficient and affordable bus service whilst others saw it as very inefficient and unreliable. Users opposing the return of conventional buses cited the long passenger waiting times which characterised the formal bus service up to the early 1990s. Their observation is correct, as average passenger waiting time was significantly reduced following introduction of minibuses (Maunder \& Mbara 1996). 
Although there was a lack of a consensus on the form of public transport that the City of Harare should adopt, there is however a strong view on a mass transport system as the backbone of public transport. It is evident from the current urban environment that public transport in Harare cannot be sustained by minibuses. The actual number of vehicles is not known, but their contribution to congestion is conspicuous. Thus sustainable transport development in the City of Harare cannot be achieved if the status quo is allowed to continue. With the continued growth in the population and an unprecedented increase in motor vehicles, the role of mass transit cannot be overemphasised.

In concluding this discussion, it is germane to make reference to Cervero's (2000) four categories of the regulatory options of acceptance, recognition, prohibition and regulation in respect of the situation in Harare. Public transport is solely provided by the informal sector (minibuses). There is therefore a compelled recognition and acceptance of the important role played by the informal sector from all four clusters of stakeholders. Whilst decision makers, academics and users recognise and accept larger-capacity buses as the ideal future public transport for the city, the reality of the situation is that such vehicles are not there and would be expensive to provide.

Prohibition and regulation are, however, complex. With a high proportion of vehicles operating illegally and the need to continue to provide a service, at times officials tend to turn a blind eye. This is compounded by the fact that police officers (law enforcement agents) who are supposed to enforce traffic regulations also own minibuses that ply the urban routes. A recent Board of Inquiry commissioned by the Police Commissioner found that $8 \%$ of the commuter omnibuses (minibuses) were owned and operated by police officers (Kadirire 2014).

\section{Conclusion}

This article has demonstrated divergent views amongst the identified four key stakeholders in urban transport operations, that is, the public sector, academia, transport operators and the users. Despite this divergence, there is greater weight towards the need for conventional buses as a sustainable mode for urban mobility, especially from the perspective of the public sector and academia. However, due to some inherent advantages associated with the informal forms of public transport, there is a need for detailed studies on how these can be integrated with the conventional buses.

From this synopsis it can be concluded that neither the formal nor the informal forms of public transport have it all: each has its own shortfalls, and therefore the need for complementary operations. All in all, this augurs well in terms of global practices of integrated public transport systems.

\section{Acknowledgements}

The authors wish to thank the following for their assistance: all interviewees in the public and private sectors, academia and transport users who voluntarily provided information, and students of the Department of Rural and Urban Planning (University of Zimbabwe) who collected data on public transport users. The Department of Transport and Supply Chain Management (University of Johannesburg) availed a token of appreciation to the students.

\section{Competing interests}

The authors declare that they have no financial or personal relationships that may have inappropriately influenced them in writing this article.

\section{Authors' contributions}

T.M. (University of Johannesburg) was the study leader and responsible for conducting some interviews and drafting the article. T.M. (University of Zimbabwe) compiled the literature review and S.D. (University of Zimbabwe) supervised students who collected data, drafted methodology and carried out some interviews.

\section{References}

Cervero, R., 1991, 'Paratransit in Southeast Asia: A market response to poor roads?', Review of Urban and Regional Development Studies 3, 3-27. http://dx.doi. org/10.1111/j.1467-940X.1991.tb00076.x

Cervero, R., 2000, State roles in providing affordable mass transport services for low-income residents, International Transport Forum Discussion paper 2011.17, University of California, Berkeley.

Golub, A.D., 2003, 'Welfare analysis of informal transit services in Brazil and the effects of regulation', PhD thesis, Institute of Transport Studies, University of California, Berkeley.

Government of Zimbabwe, 1992, Economic Structural Adjustment Programme, Government of Zimbabwe, Harare.

Government of Zimbabwe, 2012, National Transport Policy, Ministry of Transport, Harare.

Gwilliam, K., 2005, Bus franchising in Developing Countries: some recent World Bank experience, Institute of Transport Studies, University of Leeds, viewed 08 August 2013, from http://www.worldbank.org/INTURBANTRANSPORT/.../bus_franch_ gwilliam.pdf

Gwilliam, K., 2008, 'Bus transport: Is there a regulatory cycle?', Transportation Research, A, Policy and Practice 42(9), 1183-1194.

Joewono, T. \& Kubota, H., 2005, 'User perceptions of private paratransit operation in Indonesia', Journal of Eastern Asia Society for Transportation Studies 6, 262-277.

Jordan, J.D., 1983, 'Public transport in Harare', Zambesia XI, ii.

Kadirire, H., 2014, 'Chihuri bans cops from owning kombis', Dailynews, 29 January 2014, p. 3.

Kahn, A.E., 1970, The economics of regulation: Economic Principles, John Wiley, New York.

Kanyama, A. \& Carlsson-Kanyama, A., 2005, 'An analysis of the public transportation in Dar es Salaam, Tanzania, from an institutional coordination perspective', in $\mathrm{G}$. Jönsson \& E. Tengström (eds.), Coping with urban transport development: $A$ complex issue, pp. 66-68, Springer Verlag, Berlin. http://dx.doi.org/10.1007/3540-27761-7_8

Kumar, A. \& Barrett, F., 2008, 'Stuck in traffic: Urban transport in Africa', Africa Infrastructure Country Diagnostic, viewed 18 June 2013, from www.siteresources. worldbank.org/.../Resources/Stuck-in-Traffic.pdf

Maunder, D.A.C. \& Mbara T.C., 1996, The initial effects of introducing commuter omnibus services in Harare, Zimbabwe, Transport Research Laboratory, Wokingham. ISSN 0968-4107.

Portes, A., Castells, M. \& Benton, L. (eds.), 1989, The informal economy: Studies in advanced and developing countries, Johns Hopkins University Press, Baltimore.

Rakowski, C., 1994, The informal sector debate in Latin America, State University of New York Press, New York.

Sclar, E., Touber, J. \& Alexander, C., 2007, Rethinking privatisation: The case of urban transportation in Nairobi, Kenya, Centre for Sustainable Urban Development, The Earth Institute, Columbia University, New York.

Zimbabwe National Statistics Agency (ZimStat), 2012, Census 2012, Preliminary Report, ZimStat, Harare. 